\title{
Flash vacuum pyrolysis of oxazolidine-2,4-diones
}

\author{
R. Alan Aitken and Andrew W. Thomas \\ School of Chemistry, University of St Andrews, North Haugh, \\ St Andrews, Fife, KY16 9ST, UK \\ E-mail: raa@st-and.ac.uk
}

Dedicated to our good friend Douglas Lloyd to mark the occasion of his 80th birthday

\begin{abstract}
Flash vacuum pyrolysis of four oxazolidine-2,4-diones 4 at $650-750{ }^{\circ} \mathrm{C}$ leads to extrusion of $\mathrm{CO}_{2}$ to afford $\alpha$-lactams 10 (aziridinones) which fragment directly to give $\mathrm{CO}$ and an imine 12 but also rearrange to the isomeric iminooxiranes $\mathbf{1 1}$ which fragment to benzaldehyde and an isonitrile, isolated as the isomeric nitrile 15. A new by-product in the formation of one of the oxazolidinediones is identified as the 3-hydroxyazetidine-2,4-dione 5.

Keywords: Flash vacuum pyrolysis, oxazolidine-2,4-diones, iminooxiranes, carbon dioxide extrusion
\end{abstract}

\section{Introduction}

Some time ago we reported that the readily available ethyl mandelate $\mathbf{1}$ could act as a convenient acyl anion equivalent by a sequence involving deprotonation, alkylation and flash vacuum pyrolysis (FVP) to afford phenyl ketones 2.1 We later showed that the 1,3-dioxolan-4-one 3 could be used in the same way with the advantage that only one equivalent of base was required in this case. 2 As shown, both pyrolytic processes involve formation of an $\alpha$-lactone which subsequently loses $\mathrm{CO}$ to afford the product. 


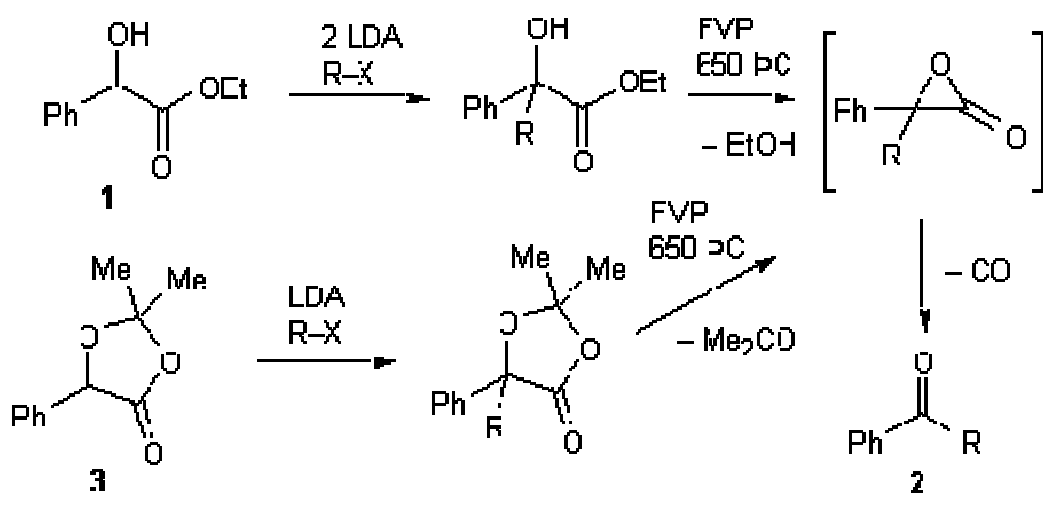

In both thesestudies the range of electrophiles used was limited to alkyl halides. In an attempt to extend the scope of these methods we considered using other types of electrophile and in this paper we report that treatment of the dianion ethyl mandelate 1 with isocyanates leads to formation of 1,3-oxazolidine-2,4-diones which decompose in an unexpected way upon FVP to afford mixtures of imines, nitriles and benzaldehyde by way of intermediate $\alpha$-lactams.

\section{Results and Discussion}

Reaction of ethyl mandelate with two equivalents of sodium hydride in THF followed by one equivalent of the appropriate isocyanate gave the expected oxazolidine-2,4-dione products $\mathbf{4}$ a-d in moderate yield. Formation of oxazolidine-2,4-diones from $\alpha$-hydroxy esters and isocyanates under a variety of conditions is well known,3 and indeed 4a was first prepared in this way in 1898.4 More recently both isothiocyanates5,6 and carbodiimides7 have been used to effect the same transformation.

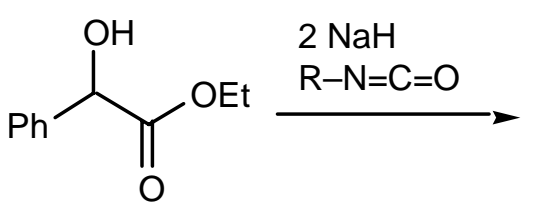

1<smiles>[R]N1C(=O)OC(c2ccccc2)C1=O</smiles>

$$
\begin{aligned}
\text { 4a } R & =P h \\
\text { b } R & =B u \\
\text { c } R & =B U^{t} \\
\text { d } R & =1 \text {-naphthyl }
\end{aligned}
$$<smiles>O=C1N(c2ccccc2)C(=O)C1(O)c1ccccc1</smiles>

5

Rather surprisingly preparation of $\mathbf{4 a}$ resulted in formation of a by-product which was readily identified by its spectroscopic data as the 3-hydroxyazetidine-2,4-dione $5[\delta \mathrm{H} 3.40(1 \mathrm{H}$, br s, $\mathrm{OH}) ; \delta \mathrm{C} 169.6(\mathrm{C}=\mathrm{O})$ and 54.9 (4ry)]. Azetidine-2,4-diones, imides of malonic acid, are a rather little known class of heterocycles and following their first synthesis by Staudinger, 8 they have 
been formed in a variety of ways.9-14 However as far as we are aware the present synthesis represents a new method. The different mechanisms by which we believe the dianion (enediolate) 6 may react to give either $\mathbf{4}$ or $\mathbf{5}$ are shown below. In an attempt to divert the reaction entirely towards the formation of 5 we added one equivalent of $\mathrm{Me} 3 \mathrm{SiCl}$ prior to the isocyanate. In fact this had the opposite effect and supressed formation of 5 completely, a result which we believe to be due to formation of $\mathbf{7}$ in which the C-acylation necessary to form $\mathbf{5}$ is blocked.<smiles>[R]NC(=O)O/C([R]([O-])=CCC)=C(/[O-])OCC</smiles><smiles>CCOC(=O)C(CC)(C(=O)Nc1ccccc1)C(OC)(C(=O)Nc1ccccc1)c1ccccc1</smiles>

6<smiles>CCOC(OC)=C([O-])c1ccccc1</smiles>

As far as we are aware, the thermal decomposition of oxazolidine-2,4-diones has not been examined before. Comparison of the pyrolytic behaviour of similar systems shows that it can be difficult to predict the course of the fragmentation.15 For example, while FVP of the 1,3oxathiolan-5-ones 8 results in clean extrusion of $\mathrm{CO} 2$ to give thiiranes, 16,17 the closely related 1,3-dioxolan-4-ones 9 do not usually lose CO2 to give epoxides, but more commonly fragment by way of an $\alpha$-lactone to give two carbonyl compounds and CO.18,2<smiles>[R]C1([R])OC(=O)C([R])([R])S1</smiles>

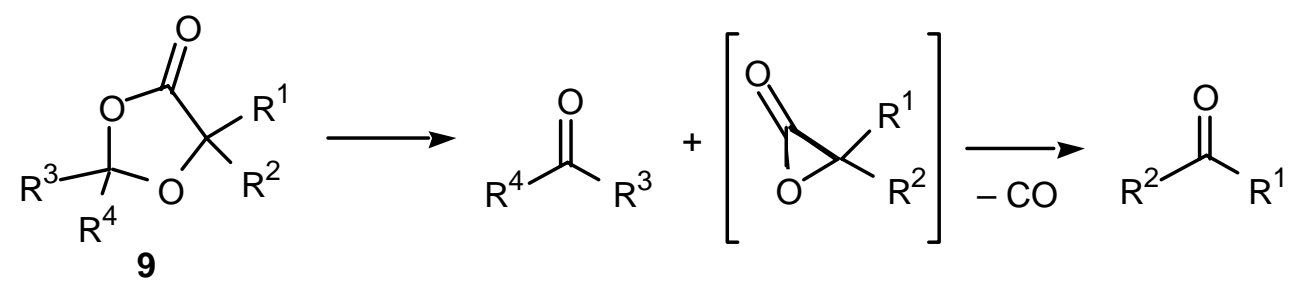


When the oxazolidinediones 4 were subjected to FVP at temperatures in the range 700 $750{ }^{\circ} \mathrm{C}$ a consistent pattern was observed. In each case the products were a mixture of benzaldehyde 13, the imines 12 and the nitriles 15 (not detected for 4c). The products together with their yields, as estimated from calibration of the NMR and GC data, are summarised in Table 1.

Table 1. Products from FVP of oxazolidine-2,4-diones (Yield, \%)

\begin{tabular}{cccccc}
\hline & $\mathbf{R}$ & $\mathbf{1 0}$ & $\mathbf{1 2}$ & $\mathbf{1 3}$ & $\mathbf{1 5}$ \\
\hline $\mathbf{a}$ & $\mathrm{Ph}$ & 15 & 27 & 27 & 10 \\
$\mathbf{b}$ & $\mathrm{Bu}$ & 5 & 33 & 33 & 38 \\
$\mathbf{c}$ & $\mathrm{But}$ & 15 & 34 & 20 & - \\
$\mathbf{d}$ & $1-\mathrm{Np}$ & - & $17 \mathrm{a}$ & 32 & 20 \\
\hline
\end{tabular}

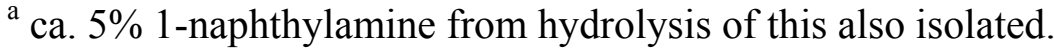

We believe that these products are accounted for by the mechanism shown in Scheme 1, in which initial extrusion of $\mathrm{CO}_{2}$ gives the $\alpha$-lactones (aziridinones) 10. These rather elusive heterocycles were only obtained as isolable compounds in the 1960's,19 but the thermal decomposition of examples bearing bulky substituents was examined in a series of papers by Sheehan, ${ }^{20-23}$ and found to give exactly the products corresponding to those obtained here. This is explained by a competition between loss of $\mathrm{CO}$ from $\mathbf{1 0}$ to give the imines $\mathbf{1 2}$ and rearrangement of $\mathbf{1 0}$ to give the isomeric iminooxiranes $\mathbf{1 1}$ which then fragment to give benzaldehyde 13 and the isonitriles 14 which under the conditions further rearrange to the more stable nitriles 15.

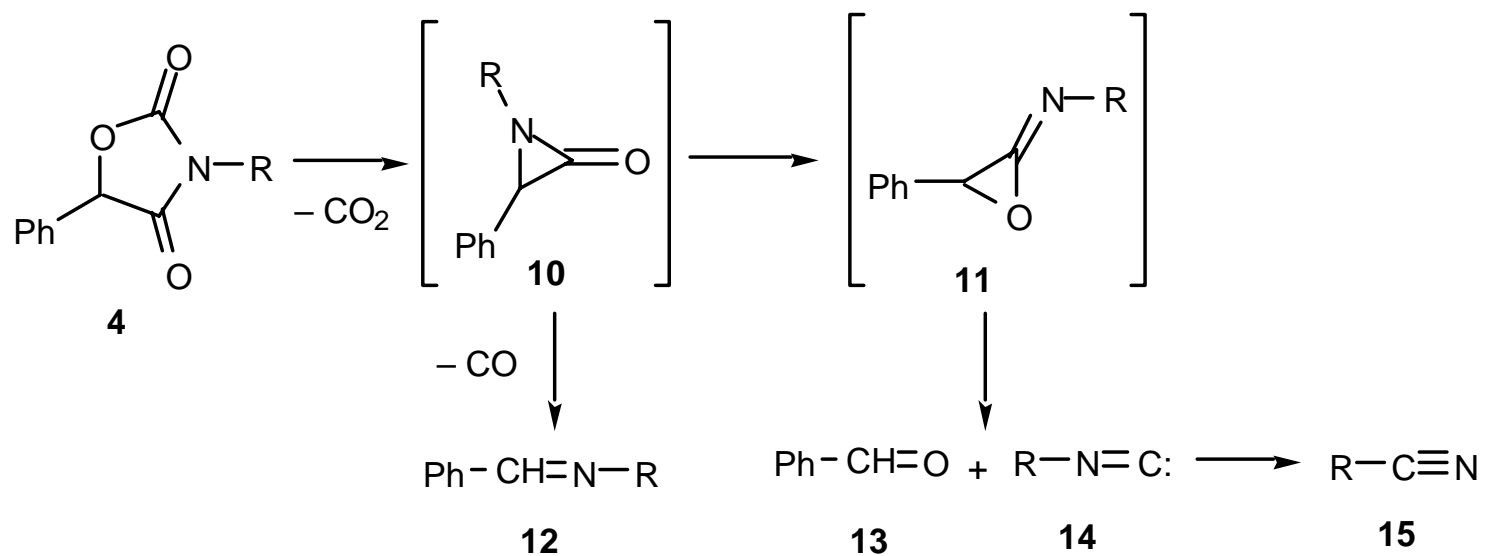

Scheme 1. Proposed mechanism for thermal decomposition of oxazolidine-2,4-diones. 
It is also notable that direct evidence for the presence of 10a (ca. 15\% yield) among the products from 4a was obtained with the observation of a singlet at $\delta_{\mathrm{H}} 3.72$ in the $1 \mathrm{H}$ NMR spectrum which compares with the value of 3.67 reported for 10c. ${ }^{24}$ GC-MS analysis showed that the products from $\mathbf{4 a - c}$ all contained minor components with the expected mass for $\alpha$-lactams 10a-c and in the last case the fragmentation pattern was in reasonable agreement with that reported for 10c. ${ }^{25}$ Of course these could also be the isomeric iminooxiranes but this seems unlikely since recent theoretical calculations have predicted the aziridinone isomer of the parent model system to be $26-31 \mathrm{~kJ}$ mol-1 more stable than the iminooxirane isomer. ${ }^{26}$

\section{Experimental Section}

General Procedures. Melting points were determined using a Reichert hot-stage microscope and are uncorrected. Infra red spectra were recorded as nujol mulls on a Perkin Elmer 1420 instrument. NMR spectra were obtained for $1 \mathrm{H}$ at $300 \mathrm{MHz}$ and for $13 \mathrm{C}$ at $75 \mathrm{MHz}$ using a Varian Gemini 2000 instrument. All spectra were run on solutions in CD3COCD3 with internal Me4Si as reference. Chemical shifts are reported in ppm to high frequency of the reference and coupling constants $J$ are in Hz. Mass spectra were obtained on an A. E. I./Kratos MS-50 spectrometer either using electron impact at $70 \mathrm{eV}$ or chemical ionisation with isobutane as the ionising gas. GC-MS studies were carried out on a Hewlett-Packard 5890A gas chromatograph coupled to a Finnigan Incos mass spectrometer.

\section{General procedure for preparation of 1,3-oxazolidine-2,4-diones}

To a suspension of $\mathrm{NaH}$ ( $60 \%$ dispersion, 2 eq.) in dry THF $(20 \mathrm{~cm} 3)$ was added a solution of ethyl $\alpha$-hydroxyphenylacetate 1 ( 1 eq.) in dry THF $(3 \mathrm{~cm} 3)$ at RT. Then a solution of the isocyanate ( 1 eq.) in dry THF $(3 \mathrm{~cm} 3)$ was added and the reaction mixture left for $18 \mathrm{~h}$. The reaction was quenched with hydrochloric acid $(1 \mathrm{M}, 35 \mathrm{~cm} 3)$ and the product extracted with ether $(30 \mathrm{~cm} 3)$. The ether layer was washed with hydrochloric acid $(1 \mathrm{M}, 2 \times 35 \mathrm{~cm} 3)$, dried and evaporated to give the product which was recrystallised as stated.

3,5-Diphenyl-1,3-oxazolidine-2,4-dione (4a). Slightly modified reaction conditions involving adding to the anion solution first trimethylsilyl chloride $(0.66 \mathrm{~g}, 0.77 \mathrm{~cm} 3,6.1 \mathrm{mmol})$ and then phenyl isocyanate $(0.73 \mathrm{~g}, 0.66 \mathrm{~cm} 3,6.1 \mathrm{mmol})$ afforded the title compound $(0.98 \mathrm{~g}, 64 \%)$ as a colourless powder from hexane-ether, mp $119-120{ }^{\circ} \mathrm{C}$ (lit.,4 $122{ }^{\circ} \mathrm{C}$ ) (Found: $\mathrm{C}, 71.4 ; \mathrm{H}, 4.4 ; \mathrm{N}$, 5.5\%; $\mathrm{M}+\mathrm{H}+, 254.0806$. $\mathrm{C} 15 \mathrm{H} 11 \mathrm{NO} 3$ requires $\mathrm{C}, 71.1 ; \mathrm{H}, 4.4 ; \mathrm{N}, 5.5 \% ; M+H, 254.0817)$; $v \max / \mathrm{cm}-1$ 1810, 1745, 1502, 1410, 1200, 1173, 762 and 697; $\delta \mathrm{H} \mathrm{7.65-7.00} \mathrm{(10} \mathrm{H,} \mathrm{m,} \mathrm{2xPh)}$ and $6.20(1 \mathrm{H}, \mathrm{s}, \mathrm{PhCH}) ; \delta \mathrm{C} 170.7(\mathrm{C}=\mathrm{O}), 154.3(\mathrm{C}=\mathrm{O}), 132.9(\mathrm{Ph}-\mathrm{C} 1), 131.9(\mathrm{NPh}-\mathrm{C} 1), 129.8$ (NPh-C4), 129.2 (NPh-C2,C6), 129.1 (Ph-C2,C6), 128.8 (Ph-C4), 127.1 (NPh-C3,C5), 126.5 $(\mathrm{Ph}-\mathrm{C} 3, \mathrm{C} 5)$ and $80.4(\mathrm{CH}) ; \mathrm{m} / \mathrm{z}(\mathrm{CI}) 254(\mathrm{M}+\mathrm{H}+, 100 \%), 210(7)$ and $65(13)$. 
Reaction using general method above gave two products separated by crystallisation. The main product was the title compound (39\%) but this was accompanied by a small amount of 3hydroxy-1,3-diphenylazetidine-2,4-dione (5) (120 mg, 29\%) from ethyl acetate-ether, mp 179$180{ }^{\circ} \mathrm{C}$ (Found: $\mathrm{M}+\mathrm{H}+, 254.0808$. $\mathrm{C} 15 \mathrm{H} 11 \mathrm{NO} 3$ requires $\left.M+H, 254.0817\right)$; vmax / cm-1 35003200, 1750, 1690 and 1600; $\delta \mathrm{H} \mathrm{7.70-7.20} \mathrm{(10} \mathrm{H,} \mathrm{m,} \mathrm{2xPh)} \mathrm{and} 3.40(1 \mathrm{H}, \mathrm{br} \mathrm{s}, \mathrm{OH}) ; \delta \mathrm{C} 169.6$ $(\mathrm{C}=\mathrm{O}), 138.5$ (Ph-C1), 129.7 (Ph-C2,C6), 129.4 (NPh-C2,C6), 129.4 (NPh-C3,C5), 126.9 (NPhC4), 125.6 (Ph-C4), 121.2 (Ph-C3,C5), 121.1 (NPh-C1) and 54.9 (4ry); m/z (CI) 254 (M+H+, $23 \%), 85$ (27) and 57 (100).

3-Butyl-5-phenyl-1,3-oxazolidine-2,4-dione (4b). Reaction as above using butyl isocyanate $(0.6 \mathrm{~g}, 0.69 \mathrm{~cm} 3,6.1 \mathrm{mmol})$ afforded the title compound $(0.58 \mathrm{~g}, 40 \%)$ as a colourless powder from hexane-ether, $\mathrm{mp} 68-70{ }^{\circ} \mathrm{C}$ (Found: $\mathrm{C}, 67.2 ; \mathrm{H}, 6.7$; N, 5.7. $\mathrm{C} 13 \mathrm{H} 15 \mathrm{NO} 3$ requires $\mathrm{C}, 66.9$; $\mathrm{H}, 6.5$; N, 6.0\%); vmax/cm-1 1803, 1740, 1338, 1196, 1130, 1008, 765 and 698; $\delta \mathrm{H} 7.50(5 \mathrm{H}$, $\mathrm{m}, \mathrm{Ph}), 6.00(1 \mathrm{H}, \mathrm{s}, \mathrm{PhCH}), 3.58$ and $3.54(2 \mathrm{H}, \mathrm{AB}$ pattern of $\mathrm{t}, J 14,7, \mathrm{CH} 2), 1.64(2 \mathrm{H}, \mathrm{m}$, $\mathrm{CH} 2), 1.35$ (2 H, m, CH2Me), 0.92 (3 H, t, J 7, CH2Me); $\delta \mathrm{C} 172.6(\mathrm{C}=\mathrm{O}), 156.5(\mathrm{C}=\mathrm{O}), 134.1$ (Ph-C1), 130.6 (Ph-C4), 130.0 (Ph-C2,C6), 127.7 (Ph-C3,C5), 81.2 (CH), 40.6 (NCH2), 30.3 (CH2), $20.4(\mathrm{CH} 2)$ and $13.8(\mathrm{Me}) ; \mathrm{m} / \mathrm{z}(\mathrm{EI}) 233(\mathrm{M}+, 55 \%), 178$ (95), 160 (59), $118(83), 105$ (80) and 90 (100).

3-t-Butyl-5-phenyl-1,3-oxazolidine-2,4-dione (4c). Reaction as above using tert-butyl isocyanate $(0.6 \mathrm{~g}, 0.7 \mathrm{~cm} 3,6.1 \mathrm{mmol})$ afforded the title compound $(0.57 \mathrm{~g}, 39 \%)$ as a colourless powder from ether, $\mathrm{mp} 63-64{ }^{\circ} \mathrm{C}$ (Found: $\mathrm{C}, 66.4 ; \mathrm{H}, 6.6$; N, 5.6. C13H15NO3 requires $\mathrm{C}, 66.9$; $\mathrm{H}, 6.5 ; \mathrm{N}, 6.0 \%)$; vmax/cm-1 1732, 1706, 1530, 1266, 1115 and 724; $\delta \mathrm{H} \mathrm{7.60-7.30} \mathrm{(5} \mathrm{H,} \mathrm{m,} \mathrm{Ph),}$ $5.80(1 \mathrm{H}, \mathrm{s}, \mathrm{PhCH})$ and $1.30(9 \mathrm{H}, \mathrm{s}, \mathrm{Me} 3) ; \delta \mathrm{C} 171.3(\mathrm{C}=\mathrm{O}), 155.0(\mathrm{C}=\mathrm{O}), 136.6(\mathrm{Ph}-\mathrm{C} 1), 129.7$ (Ph-C4), 129.6 (Ph-C2,C6), 128.7 (Ph-C3,C5), $74.6(\mathrm{CH}), 50.9$ (4ry) and 29.1 (Me3); m/z (EI) $233(\mathrm{M}+, 5 \%), 192(10), 152$ (100), 135 (89), 107 (90) and 57 (61).

3-(1-Naphthyl)-5-phenyl-1,3-oxazolidine-2,4-dione (4d). Reaction as above using 1-naphthyl isocyanate $(1.0 \mathrm{~g}, 0.88 \mathrm{~cm} 3,6.1 \mathrm{mmol})$ afforded the title compound $(0.69 \mathrm{~g}, 37 \%)$ as a colourless powder from hexane-ether, mp $162-163{ }^{\circ} \mathrm{C}$ (Found: $\mathrm{M}+, 303.0888$. C19H13NO3 requires $M$, 303.0895); vmax/cm-1 1709, 1547, 1226, 1117, 794, 764 and 728; $\delta \mathrm{H} \mathrm{8.30-7.30} \mathrm{(12} \mathrm{H,} \mathrm{m,} \mathrm{Ar)}$ and $6.00(1 \mathrm{H}, \mathrm{s}, \mathrm{PhCH})$; $\delta \mathrm{C} 170.1(\mathrm{C}=\mathrm{O}), 154.1(\mathrm{C}=\mathrm{O}), 135.1$ (4ry), 134.4 (4ry), 133.7 (4ry), $129.1(\mathrm{CH}), 128.7(2 \mathrm{CH}), 128.4(\mathrm{CH}), 128.0(4 \mathrm{ry}), 127.9(2 \mathrm{CH}), 126.8(\mathrm{CH}), 126.1(\mathrm{CH}), 126.0$ $(\mathrm{CH}), 125.7(\mathrm{CH}), 125.2(\mathrm{CH}), 122.3(\mathrm{CH})$ and $74.7(\mathrm{CH}) ; \mathrm{m} / \mathrm{z}(\mathrm{EI}) 303(\mathrm{M}+, 28 \%), 232(45)$, 187 (70), 169 (55), 143 (100), 135 (70), 115 (80) and 107 (53). 


\section{General Procedure for pyrolysis of 1,3-oxazolidine-2,4-diones}

The sample was volatilised from a tube in a Büchi Kugelrohr oven through a 30x2.5 cm horizontal fused quartz tube. This was heated externally by a Carbolite Eurotherm tube furnace $\mathrm{MTF}-12 / 38 \mathrm{~A}$ at a temperature of $650-750{ }^{\circ} \mathrm{C}$, the temperature being monitored by a Pt / Pt$13 \% \mathrm{Rh}$ thermocouple situated at the centre of the furnace. The products were collected in a Ushaped trap cooled in liquid nitrogen. The whole system was maintained at a pressure of 10-2 Torr by an Edwards Model E2M5 high capacity rotary oil pump, the pressure being measured by a Pirani gauge situated between the cold trap and the pump. Under these conditions the contact time in the hot zone was estimated to $b e \approx 10 \mathrm{~ms}$.

After the pyrolysis, the system was opened to the air and the products removed for analysis. In this study all products were identified by comparison of GC-MS and NMR data with authentic samples and/or literature values. Only selected diagnostic data are given below

FVP of 4a (101.3 mg, $650{ }^{\circ} \mathrm{C}, 2.6 \times 10-2$ Torr) gave a red liquid-solid at the furnace exit and a colourless liquid in the cold trap. These consisted of i) benzaldehyde $13(27 \%)[\delta \mathrm{H} 10.0(1 \mathrm{H}, \mathrm{s})$ and 7.89 (2 H, m); $\delta \mathrm{C} 192.7$ (CO), 136.5 (4ry), 134.6, 129.9 (2 C) and 129.1 (2 C); m/z 106 (M+, 50\%), 105 (70), 77 (100) and 51 (75)], ii) $N$-benzylideneaniline 12a (27\%) [ $\delta \mathrm{H} 8.40(1 \mathrm{H}, \mathrm{s}) ; \delta \mathrm{C}$ $160.5(\mathrm{CH}=\mathrm{N}) ; \mathrm{m} / \mathrm{z} 181(\mathrm{M}+, 30 \%), 180$ (50), $104(12), 77$ (100) and 51 (55)], iii) 1,3diphenylaziridin-2-one 10a (15\%) [ $\delta \mathrm{H} 3.72(1 \mathrm{H}, \mathrm{s}, \mathrm{CH}) ; \mathrm{m} / \mathrm{z} 209(\mathrm{M}+, 30 \%), 180(100), 152$ (10), 77 (37) and 51 (41)], iv) benzonitrile 15a (10\%) [ $\delta \mathrm{C} 110.5(\mathrm{CN}) ; \mathrm{m} / \mathrm{z} 103(\mathrm{M}+, 100 \%), 76$ (48) and $50(34)]$ and v) starting material (17\%).

FVP of the $4 a\left(83.7 \mathrm{mg}, 750{ }^{\circ} \mathrm{C}, 1.56 \times 10-2\right.$ Torr) gave a liquid-solid at the furnace exit and a colourless liquid in the cold trap. These were similar to above with only $5 \%$ starting material recovered.

FVP of the $4 \mathbf{b}\left(83.3 \mathrm{mg}, 700{ }^{\circ} \mathrm{C}, 3.0 \times 10-2\right.$ Torr) gave a red liquid-solid at the furnace exit and a colourless liquid in the cold trap. These consisted of i) valeronitrile 15b $(38 \%)[\delta \mathrm{H} 2.40(2 \mathrm{H}, \mathrm{t}$, $\mathrm{CH} 2 \mathrm{CN}), 1.60(2 \mathrm{H}, \mathrm{m}), 1.40(2 \mathrm{H}, \mathrm{m})$ and $0.90(3 \mathrm{H}, \mathrm{t}) ; \delta \mathrm{C} 120.8(\mathrm{CN}), 28.2,22.5,16.8$ and 13.5; m/z $82(\mathrm{M}-\mathrm{H}+, 2 \%), 54(31), 41$ (100) and $27(68)]$, ii) benzaldehyde $13(33 \%)$ [ $\delta \mathrm{H}, \delta \mathrm{C}$ and $\mathrm{m} / \mathrm{z}$ as above] iii) $\mathrm{N}$-benzylidenebutylamine $\mathbf{1 2 b}(33 \%)[\delta \mathrm{H} 8.40(1 \mathrm{H}, \mathrm{s}, \mathrm{CH})$ and $3.60(2 \mathrm{H}$, t, CH2); $\delta \mathrm{C} 161.3(\mathrm{CH}=\mathrm{N}), 133.8$ (4ry), 131.4, 129.6 (2 C), 129.0 (2 C), 61.8, 33.9, 21.1 and 14.2; m/z $161(\mathrm{M}+, 3 \%), 160(6), 132(15), 118(61)$ and 91 (100)] iv) 1-butyl-3-phenylaziridin2-one 10b (5\%) [m/z $189(\mathrm{M}+, 18 \%), 146(20), 118(100)$ and 91 (35)] and starting material $(14 \%)$.

FVP of the $4 \mathrm{c}\left(110.8 \mathrm{mg}, 700{ }^{\circ} \mathrm{C}, 2.0 \times 10-2\right.$ Torr $)$ gave a liquid-solid at the furnace exit and a colourless liquid in the cold trap. These consisted of i) $N$-benzylidene-t-butylamine 12c (34\%) [ $\delta \mathrm{H} 8.40(1 \mathrm{H}, \mathrm{s}, \mathrm{CH})$ and $1.40(9 \mathrm{H}, \mathrm{s}, \mathrm{CMe} 3) ; \delta \mathrm{C} 155.1(\mathrm{C}=\mathrm{N}), 137.5(4 \mathrm{ry}), 130.2,128.5(2 \mathrm{C})$, 128.0 (2 C), 54.1 (4ry) and 29.0 (3 C); m/z 161 (M+, 8\%), 146 (82), 104 (35), 57 (95) and 41 (100)] ii) benzaldehyde $13(20 \%)$ [ $\delta \mathrm{H}, \delta \mathrm{C}$ and $\mathrm{m} / \mathrm{z}$ as above] and iii) 1-t-butyl-3-phenylaziridin2-one 10c (15\%) [m/z $189(\mathrm{M}+, 8 \%), 92(44)$ and $57(100)]$. 
FVP of the $4 \mathbf{d}\left(95.6 \mathrm{mg}, 700{ }^{\circ} \mathrm{C}, 1.4 \times 10-2\right.$ Torr) gave a solid at the furnace exit and a colourless liquid in the cold trap. These consisted of i) benzaldehyde $13(32 \%)[\delta \mathrm{H}, \delta \mathrm{C}$ and $\mathrm{m} / \mathrm{z}$ as above], ii) $\mathrm{N}$-benzylidene-1-naphthylamine 12d $(17 \%)[\delta \mathrm{H} 8.70(1 \mathrm{H}, \mathrm{s}, \mathrm{CH}) ; \mathrm{m} / \mathrm{z} 231(\mathrm{M}+$, 60\%), 230 (68), 154 (25), 127 (100), 77 (50) and 51 (40)], iii) 1-naphthonitrile (20\%) 15d [m/z $153(\mathrm{M}+, 100 \%)$ and $126(28)]$ and 1-naphthylamine $(5 \%)[\delta \mathrm{H} 6.80(1 \mathrm{H}, \mathrm{dd}, J 8,2)$ and $6.70(1$ $\mathrm{H}, \mathrm{d}, J$ 8); $\mathrm{m} / \mathrm{z} 143(\mathrm{M}+, 100 \%)$ and $115(85)]$.

\section{References and Notes}

1. Aitken, R. A.; Thomas, A. W. Synlett 1997, 293.

2. Aitken, R. A.; Thomas, A. W. Synlett 1998, 102.

3. Clark-Lewis, J. W. Chem. Rev. 1958, 58, 63.

4. Lambling, E. C. R. Hebd. Seances Acad. Sci. 1898, 127, 188.

5. Shibuya, I.; Goto, M.; Shimizu, M.; Yanagisawa, M.; Gama, Y. Heterocycles 1999, 51, 2667.

6. Gama, Y.; Shibuya, I.; Shimizu, M. J. Carbohydr. Chem. 2000, 19, 119.

7. Noguchi, S.; Fujii, A.; Hashitani, K.; Ishizu, T. Chem. Pharm. Bull. 1994, 42, 1567.

8. Staudinger, H.; Göhring, O.; Schöller, M. Ber. Dtsch. Chem. Ges. 1914, 47, 40.

9. Ebnöther, A.; Jucker, E.; Rissi, E.; Rutschmann, J.; Schreier, E.; Steiner, R.; Süess, R.; Vogel, A. Helv. Chim. Acta 1959, 42, 918.

10. Kanaoka, Y.; Okajima, H.; Hatanaka, Y. J. Org. Chem. 1979, 44, 1749.

11. Maruyama, K.; Ishitoku, T.; Kubo, Y. J. Am. Chem. Soc. 1979, 101, 3670.

12. Maruyama, K.; Ishitoku, T.; Kubo, Y. J. Org. Chem. 1981, 46, 27.

13. Aoyama, H.; Sakamoto, M.; Omote, Y. J. Chem. Soc., Chem. Commun. 1982, 119.

14. Bari, S. S.; Trehan, I. R.; Sharma, A. K.; Manhas, M. S. Synthesis 1992, 439.

15. Aitken, R. A.; Thomas, A. W. In The chemistry of double-bonded functional groups; Supplement A3, Patai, S., Ed.; John Wiley \& Sons Ltd, Chichester, 1997, Ch. 10, pp 473536.

16. Cameron, T. B.; Pinnick, H. W. J. Am. Chem. Soc. 1979, 101, 4755.

17. Cameron, T. B.; Pinnick, H. W. J. Am. Chem. Soc. 1980, 102, 744.

18. Cameron, T.B.; El-Kabbani, F. M.; Pinnick, H. W. J. Am. Chem. Soc. 1981, 103, 5414.

19. Lengyel, I.; Sheehan, J. C. Angew. Chem., Int. Ed. 1968, 7, 25.

20. Sheehan, J. C.; Lengyel, I. J. Am. Chem. Soc. 1964, 86, 1356.

21. Sheehan, J. C.; Lengyel, I. J. Am. Chem. Soc. 1964, 86, 746.

22. Sheehan, J. C.; Beeson, J. H. J. Am. Chem. Soc. 1967, 89, 362.

23. Sheehan, J. C.; Beeson, J. H. J. Am. Chem. Soc. 1967, 89, 366.

24. Baumgarten, H. E.; Chiang, N.-C. R.; Elia, V. J.; Beum, P. V. J. Org. Chem. 1985, 50, 5507. 
25. Baumgarten, H. E.; Parker, R. G.; von Minden, D. L. Org. Mass Spectrom. 1969, 2, 1221.

26. Quast, H.; Leybach, H.; Würthwein, E.-U. Chem. Ber. 1992, 125, 1249. 